\section{Evaluation of Sweetpotato Cultivars with Varying Canopy Architectures in Conventional and a Reduced-tillage Rye Production System}

\author{
Stephen C. Smith ${ }^{1}$, Katherine M. Jennings ${ }^{1}$, David W. Monks ${ }^{1}$, \\ David L. Jordan ${ }^{2}$, S. Chris Reberg-Horton ${ }^{2}$, and \\ Michael R. Schwarz ${ }^{3}$
}

soybean (Glycine max), cover crops are used to reduce reliance on cultivation while increasing soil health. Planting into a rye (Secale cereal) cover crop mulch can increase soil organic matter content (DeLaune et al., 2019; Moore et al., 2014), decrease compaction over the long-term ( $>10$ years) (BlancoCanqui et al., 2010; DeLaune et al., 2019), and reduce nutrient runoff by increasing water infiltration and soil water storage, and storage of residual nitrate in residue (DaLaune et al., 2019; Hartwig, 1988; Kessavalou and Walters, 1999; Langdale and Leonard, 1983).

High-residue rye cover crop mulch in sweetpotato production has the potential to reduce the need for and impact of tillage. Treadwell et al. (2007) reported similar yield between conventional tillage compared with reduced-tillage sweetpotato grown in a rye mulch system in 2 of 3 years in North Carolina. However, this system-based study had varying nitrogen (N) sources as well as levels of weed interference. Similarly, the use of a wheat (Triticum aestivum) straw mulch reduced weed biomass without a significant effect on sweetpotato yield in an organic production system in Tennessee (Nwosisi et al., 2019).

Along with altered production systems, sweetpotato cultivars with varying canopy architectures have potential to reduce in-season cultivation for weed control. Under season-long weed interference, 'Carolina Bunch' (upright architecture) had greater storage root yield than 'Beauregard' (prostrate architecture) in 2 of 3 years (Harrison and Jackson, 2011). Additionally, weeds competing with 'Carolina Bunch' tended to have less biomass than those competing with 'Beauregard', suggesting that upright sweetpotato cultivars could be better suited to compete with weeds (Harrison and Jackson, 2011).

Information in the peer-reviewed literature is limited with respect to publication 10 Dec. 2021

Published online 8 February 2022

${ }^{1}$ Department of Horticultural Science, North Carolina State University, Raleigh, NC 27695-7609

${ }^{2}$ Department of Crop and Soil Sciences, North Carolina State University, Raleigh, NC 27695-7620

${ }^{3}$ Department of Entomology and Plant Pathology, North Carolina State University, Raleigh, NC 27695 7613

S.C.S. is the corresponding author. E-mail: scsmith7@ ncsu.edu.

This is an open access article distributed under the CC BY-NC-ND license (https://creativecommons. org/licenses/by-nc-nd/4.0/).

https://doi.org/10.21273/HORTTECH04912-21

\begin{tabular}{llll}
\hline $\begin{array}{l}\text { Units } \\
\begin{array}{l}\text { To convert U.S. to SI, } \\
\text { multiply by }\end{array}\end{array}$ & U.S. unit & SI unit & $\begin{array}{l}\text { To convert SI to U.S., } \\
\text { multiply by }\end{array}$ \\
\hline 0.4047 & acre(s) & ha & 2.4711 \\
0.3048 & $\mathrm{ft}$ & $\mathrm{m}$ & 3.2808 \\
0.0929 & $\mathrm{ft}^{2}$ & $\mathrm{~m}^{2}$ & 10.7639 \\
2.54 & inch(es $)$ & $\mathrm{cm}^{3}$ & 0.3937 \\
16.3871 & inch & $\mathrm{cm}^{3}$ & 0.0610 \\
1.1209 & $\mathrm{lb} / \mathrm{acre}^{3}$ & $\mathrm{~kg} \cdot \mathrm{ha}^{-1}$ & 0.8922 \\
1.7300 & $\mathrm{oz} /$ inch & $\mathrm{g} \cdot \mathrm{cm}^{-3}$ & 0.5780 \\
2.2417 & ton $(\mathrm{s}) / \mathrm{acre}$ & $\mathrm{t} \cdot \mathrm{ha}^{-1}$ & 0.4461 \\
$\left({ }^{\circ} \mathrm{F}-32\right) \div 1.8$ & ${ }^{\circ} \mathrm{F}$ & ${ }^{\circ} \mathrm{C}$ & $\left({ }^{\circ} \mathrm{C} \times 1.8\right)+32$ \\
& & &
\end{tabular}


high-residue rye cover crop mulch system on otherwise conventionally managed sweetpotato. Thus, studies were conducted to determine the effect of production systems (reduced-tillage, high-residue rye cover crop mulch; conventional no mulch) on soil bulk density and moisture, and growth and storage root yield of sweetpotato cultivars having different vining (upright or prostrate) characteristics.

\section{Materials and methods}

Field studies were conducted at the Horticultural Crops Research Station near Clinton, NC [HCRS (lat. $35.02^{\circ} \mathrm{N}$, long. $\left.78.28^{\circ} \mathrm{W}\right)$ ] and the Cunningham Research Station in Kinston, NC (CURS (lat. $35.30^{\circ} \mathrm{N}$, long. $\left.\left.77.57^{\circ} \mathrm{W}\right)\right]$ in 2019 , and the Caswell Research Station in Kinston, NC [CARS (lat. $35.27^{\circ} \mathrm{N}$, long. $77.61^{\circ} \mathrm{W}$ )] in 2020. Soils were an Orangeburg (fine-loamy, kaolinitic, thermic Typic Kandiudults), Norfolk (fine-loamy, kaolinitic, thermic Typic Kandiudults), and Kenansville (loamy, siliceous, subactive, thermic Arenic Hapludults) loamy sand at HCRS, CURS, and CAS respectively. Soil organic matter content was $<1 \%$ and $\mathrm{pH} 6$ to 6.5 at all locations.

Studies were initiated in the fall by disking the entire site. Plots receiving the reduced-tillage rye treatment were then plowed with a ripper bedder to produce 42 -inch-wide bedded rows. Plots assigned to receive the conventional treatment were not bedded until June of the following year. 'Wrens Abruzzi' cereal rye seeds were then immediately broadcast at $120 \mathrm{lb} /$ acre across the entire study (Table 1 ). Nitrogen was applied to the entire study area in December $(30 \mathrm{lb} / \mathrm{acre})$ and February $(60 \mathrm{lb} / \mathrm{acre})$ to maximize rye biomass production. Cereal rye in conventional plots was killed using glyphosate at $1.24 \mathrm{~kg} \cdot \mathrm{ha}^{-1}$ ae on 11 Mar. 2019 and 4 Feb. 2020. Rye in reduced-tillage plots was allowed to natural senesce without chemical termination. One day before planting, nonrooted sweetpotato cuttings were cut from seeds beds located at HCRS and conventional plots were plowed to produce 42 -inch-wide bedded rows. Nonrooted sweetpotato cuttings were transplanted into conventional plots, and directly through the standing rye in reduced-tillage plots using a commercial mechanical transplanter (Checchi and Magli, Lehi, UT) calibrated for $\mathrm{l}-\mathrm{ft}$ in-row spacing. Phosphorous $(60$ $\mathrm{lb} / \mathrm{acre}$ ) and potassium (152 lb/acre) were broadcast across the entire study area at 2 weeks after planting. Nitrogen (46.5 $\mathrm{lb} /$ acre) was broadcast across the entire study area at 4 weeks after planting. Fertilizer applications were followed by a cultivation event in conventional plots only. Weeds were controlled season long using a combination of herbicides, cultivation, and handroguing. The herbicide program used in both systems consisted of $0.9 \mathrm{lb} / \mathrm{acre}$ flumioxazin (Valor SX; Valent USA Corp., Walnut Creek, CA) preplant, $0.75 \mathrm{lb} /$ acre clomazone (Command 3ME; FMC Corp., Philadelphia, PA) 0 to $2 \mathrm{~d}$ after transplanting (DAP), 0.7 $\mathrm{lb} /$ acre $S$-metolachlor (Dual Magnum; Syngenta Corp, Greensboro, NC) 7 to $10 \mathrm{DAP}$, and $0.045 \mathrm{lb} /$ acre clethodim (Select Max; Valent USA Corp.) postemergent as needed for emerged grass control. Escaped weeds $>8 \mathrm{~cm}$ were controlled by hand-roguing across the study, and cultivation was used as needed in conventional plots. To control root-feeding insects, $0.09 \mathrm{lb} /$ acre bifenthrin (Sniper; Loveland Products, Greeley CO) was broadcast across the entire study area at 4 weeks after

Table 1. Cover crop (cereal rye) seeding, sweetpotato transplant and harvest dates, and cumulative precipitation at the Horticultural Crops Research Station (Clinton NC), Cunningham Research Station (Kinston, NC), and Caswell Research Station (Kinston NC).

\begin{tabular}{llll}
\hline & \multicolumn{3}{c}{ Location } \\
\cline { 2 - 4 } Event & $\begin{array}{c}\text { Horticultural } \\
\text { Crops Research } \\
\text { Station }\end{array}$ & $\begin{array}{c}\text { Cunningham } \\
\text { Research } \\
\text { Station }\end{array}$ & $\begin{array}{c}\text { Caswell } \\
\text { Research } \\
\text { Station }\end{array}$ \\
\hline Rye seeding & 25 Oct. 2018 & 29 Nov. 2018 & 22 Oct. 2019 \\
Sweetpotato planting & 3 June 2019 & 5 June 2019 & 9 June 2020 \\
Sweetpotato harvest & 26 Sept. 2019 & 24 Sept. 2019 & 8 Oct. 2020 \\
Cumulative precipitation $(\mathrm{cm})^{\mathrm{z}}$ & 73.86 & 42.47 & 64.56 \\
\hline
\end{tabular}

${ }^{\mathrm{z}}$ Precipitation for sweetpotato growing season only; $1 \mathrm{~cm}=0.3937$ inch. planting for control of root feeding insects. Insecticide applications were followed by a cultivation event in conventional plots only.

Treatments included a high-residue, rye cover crop mulch system (reduced-tillage rye system) and a conventional production system. Within each production system, the sweetpotato cultivars Covington, Bayou Belle, NC01-0531, and NCl5-650 were evaluated for performance. 'Covington' and 'Bayou Belle' have low-growing prostrate vine architectures (Yencho et al., 2008). 'NC04-0531' and 'NCl5650 ' were bred for organic production and have upright vine architectures. The study was a split-plot design with production system as the whole-plot factor and cultivar as the split-plot factor. Splitplots were three rows each $20 \mathrm{ft}$ long. The first and third rows were border rows. The second was a data collection row. Whole-plots were completely randomized design with four replications.

Data collected included cover crop biomass, soil volumetric water content and bulk density, and sweetpotato canopy height and width, time to canopy closure, and storage root yield and shape. Rye cover crop biomass was collected 1 week after planting (WAP) sweetpotato. To calculate biomass, two $1-\mathrm{m}^{2}$ quadrats were placed randomly within each reducedtillage rye whole-plot and then all aboveground rye biomass was collected, placed immediately into paper bags, dried at $70^{\circ} \mathrm{C}$ for 1 week and then weighed. Sweetpotato canopy height and width, and soil volumetric water content were measured every 2 weeks from 2 to 12 WAP. Sweetpotato canopy height and canopy width were measured at three random points per split-plot from the soil surface at the top of the bed to the uppermost leaf and perpendicular to the row from leaf tip to leaf tip, respectively. Soil volumetric water content was measured to a depth of $12 \mathrm{~cm}$ at three random points, along the top of the bed but $\geq 10 \mathrm{~cm}$ from crown of sweetpotato plants, per split-plot using a soil moisture meter (FieldScout TDR 350; Spectrum Technologies, Aurora, IL) soil moisture meter. Soil bulk density was measured at 2 and 10 WAP by collecting $90.6 \mathrm{~cm}^{3}$ of nondisturbed soil per split-plot from the top of the bed to a depth of $5 \mathrm{~cm}$ using a core sampler (AMS, 
American Falls, ID). Soil was then dried at $70{ }^{\circ} \mathrm{C}$ for 1 week and then weighed. Sweetpotato storage roots were harvested 116, 112, and $122 \mathrm{DAP}$ at HCRS, CURS, and CARS, respectively, using a sweetpotato disk plow (Strickland Bros. Enterprises, Spring Hope, NC). Storage roots were collected by hand for each treatment and graded using a high-throughput optical grader (Exeter Engineering, Exeter, CA) into jumbo ( $>3.5$ inches diameter), US No. $1(>1.75$ inch but $<3.5$ inches diameter and $>3$ inches but $<9$ inches length), canner $(>1$ inch but $<1.75$ inch diameter and $>2$ inch but $<7$ inches length), and cull (all other roots) (USDA, Agriculture Marketing Service, 2019). Marketable yield was calculated as the sum of jumbo, US No. 1, and canner grades. The optical grader was also used to collect root length to width ratio measurements on all harvested roots.

Homogeneity of variance and normality were determined before analysis of variance (ANOVA) by plotting residuals. Jumbo, canner, and cull root weights and counts were subjected to square root transformation. Storage root length to width ratio was subjected to $\log$ transformation. Transformed data were subjected to ANOVA using PROC MIXED (SAS version 9.4; SAS Institute, Cary, NC). Cultivar, production system, and their interaction were treated as fixed effects. Location and whole-plot nested within production system were treated as random effects. When appropriate, means were separated using Tukey's honestly significant difference $(P>0.05)$. Nonlinear regression (SAS PROC NLIN) was carried out on least square means, separately by production system, to describe canopy growth of cultivars over time.

The three-parameter logistic model was used to describe the relationship between canopy height and weeks after planting (Smith et al., 2020):

$$
\mathrm{Y}=\mathrm{a} /[(1+\mathrm{c}) \times \exp (-\mathrm{b} \times \mathrm{T})],
$$

where $\mathrm{Y}$ is the sweetpotato canopy height (centimeters), $\mathrm{a}$ is the upper asymptote, $\mathrm{T}$ is weeks after planting, $\mathrm{c}$ and $b$ are constants.

\section{Results}

Rye cover crop dry biomass was $6300 \mathrm{~kg} \cdot \mathrm{ha}^{-1}$ at CURS and HCRS and $9100 \mathrm{~kg} \cdot \mathrm{ha}^{-1}$ at CARS and was consistent with other research in

Table 2. Effects of four sweetpotato cultivars and two production systems on sweetpotato canopy width at 2,4 , and 6 weeks after planting (WAP).

\begin{tabular}{|c|c|c|c|}
\hline & $2 \mathrm{WAP}$ & $4 \mathrm{WAP}$ & $6 \mathrm{WAP}$ \\
\hline & \multicolumn{3}{|c|}{ Canopy width $(\mathrm{cm})^{\mathrm{z}}$} \\
\hline \multicolumn{4}{|l|}{ Cultivar } \\
\hline Covington & $9 \mathrm{a}^{\mathrm{y}}$ & $18 \mathrm{a}$ & $62 \mathrm{a}$ \\
\hline Bayou Belle & $12 \mathrm{a}$ & $18 \mathrm{a}$ & $66 \mathrm{a}$ \\
\hline NC04-0531 & $10 \mathrm{a}$ & $18 \mathrm{a}$ & $42 \mathrm{~b}$ \\
\hline NC15-0650 & $13 a$ & $20 \mathrm{a}$ & $45 \mathrm{~b}$ \\
\hline \multicolumn{4}{|l|}{ Production system } \\
\hline Conventional & $12 \mathrm{a}$ & $22 \mathrm{a}$ & $62 \mathrm{a}$ \\
\hline $\begin{array}{l}\text { Reduced-tillage } \\
\text { rye }^{\mathrm{x}}\end{array}$ & $10 \mathrm{a}$ & $15 \mathrm{~b}$ & $46 \mathrm{~b}$ \\
\hline
\end{tabular}

North Carolina (Smith et al., 2011; Yenish et al., 1996).

SoIL MOISTURE. The interaction of production system and cultivar was not significant $(P>0.05)$; therefore, soil volumetric water content was combined across cultivars. Because of rainfall differences, soil volumetric water content data were analyzed by location and measurement timing. Volumetric water content was similar for both systems the majority of each season except during periods of drought (soil volumetric water content $<8 \%$ ) (Table 4 ). At CURS volumetric water content was greater in the reduced-tillage rye system at $8 \mathrm{WAP}$. The same trend was observed at HCRS at 10 WAP. These results support the findings of Daigh et al. (2014) who observed similar results in soybean during extreme drought. These data suggest that during periods of drought, reduced-tillage rye cover crop systems may have more plant available water than conventional systems.

SOIL BULK DENSITY. The interaction of production system and cultivar was not significant $(P>0.05)$; therefore, soil bulk density was combined across cultivars. Soil bulk density in the reduced-tillage rye system was $5 \%$ and $7 \%$ higher than the conventional tillage system at 2 and $10 \mathrm{WAP}$, respectively (Table 5). Soil bulk density for both systems at each timing was within the recommended range $\left(<1.6 \mathrm{~g} \cdot \mathrm{cm}^{-3}\right)$ for root growth in a sandy soil (USDA, Natural Resource Conservation Service, 2008). Although soil bulk density increased throughout the season, previous research indicates that long-term decreases in tillage could have the opposite effect on soil bulk density (Blanco-Canqui et al., 2010; DeLaune et al., 2019)

SWEETPOTATO CANOPY GROWTH. The interaction of production system and cultivar was not significant $(P>$ 0.05 ); therefore, only the main effects of production system and cultivar are presented for canopy width. Early season ( 0 to 4 WAP) canopy width in conventional and reduced-tillage rye systems was similar regardless of cultivar (Table 2 ). After lay-by ( $\approx 5 \mathrm{WAP})$, differences began to emerge between cultivars. At 6 WAP, 'Covington' (62 $\mathrm{cm})$ and 'Bayou Belle' $(66 \mathrm{~cm})$ had greater canopy width than 'NC040531' (42 cm) and 'NC15-0650' (45 $\mathrm{cm})$. As expected, canopy width expansion of upright cultivars was slower than that of prostrate cultivars regardless of system. Averaged across sweetpotato cultivars, the conventional tillage system resulted in sweetpotato with $50 \%$ and $65 \%$ greater canopy width than the reduced-tillage rye system at 4 and 6 WAP respectively (Table 2 ).

Production system by cultivar interaction was significant $(P<0.05)$ for sweetpotato canopy height; therefore, separate models were fit for each cultivar by production system combination. The relationship between sweetpotato canopy height and week after planting was described with a logistics model (Table 3, Fig. 1). The models describing canopy height are similar until late in the season. At 10 and 12 WAP, canopy height of prostrate cultivars was greater than that of upright cultivars. All models describing prostrate cultivars have estimated 
Table 3. Parameter estimates for the logistic model for sweetpotato canopy height of four sweetpotato cultivars within a conventional or reduced-tillage rye production system.

\begin{tabular}{|c|c|c|c|c|c|c|}
\hline \multirow[b]{2}{*}{ Cultivar } & \multirow[b]{2}{*}{ Production system } & \multicolumn{3}{|c|}{ Parameter estimates ${ }^{\mathrm{z}}$} & \multirow[b]{2}{*}{ RMSE } & \multirow[b]{2}{*}{ EF } \\
\hline & & $\mathbf{a}(\mathrm{SE})$ & b (SE) & $c(S E)$ & & \\
\hline Covington & Reduced-tillage rye ${ }^{y}$ & $99.0(130)$ & $0.15(0.07)$ & $10.6(13.3)$ & 1.86 & 0.99 \\
\hline \multirow[t]{2}{*}{ Bayou Belle } & Reduced-tillage rye & $377.0(3030)$ & $0.15(0.09)$ & $47.5(377)$ & 2.92 & 0.99 \\
\hline & Conventional & $86.2(68.2)$ & $0.25(0.11)$ & $15.9(8.2)$ & 3.86 & 0.99 \\
\hline NC04-0531 & Reduced-tillage rye & $65.0(44.8)$ & $0.22(0.11)$ & $7.9(3.9)$ & 3.33 & 0.99 \\
\hline NC15-0650 & Conventional & $52.2(4.7)$ & $0.33(0.05)$ & $8.9(1.5)$ & 1.49 & 0.99 \\
\hline
\end{tabular}

${ }^{\mathrm{z}}$ Logistic equation: $\mathrm{Y}=\mathrm{a} /[(\mathrm{l}+\mathrm{c}) \times \exp (-\mathrm{b} \times \mathrm{T})]$, where $\mathrm{Y}$ is the sweetpotato canopy height (centimeters), a is the upper asymptote, $\mathrm{T}$ is weeks after planting, $\mathrm{c}$ and $\mathrm{b}$ are constants.

${ }^{\mathrm{y}}$ Reduced-tillage rye production system consisted of sweetpotato transplanted through a standing rye cover crop onto beds. No in-season cultivation was conducted. $\mathrm{SE}=$ standard error; RMSE $=$ root mean square error; $\mathrm{EF}=$ modeling efficiency coefficient.

maximum heights $>84 \mathrm{~cm}$. Conversely, models describing upright cultivars have estimated maximum heights of $\leq 65 \mathrm{~cm}$. Although estimated maximum heights are likely an overestimation of final canopy height,

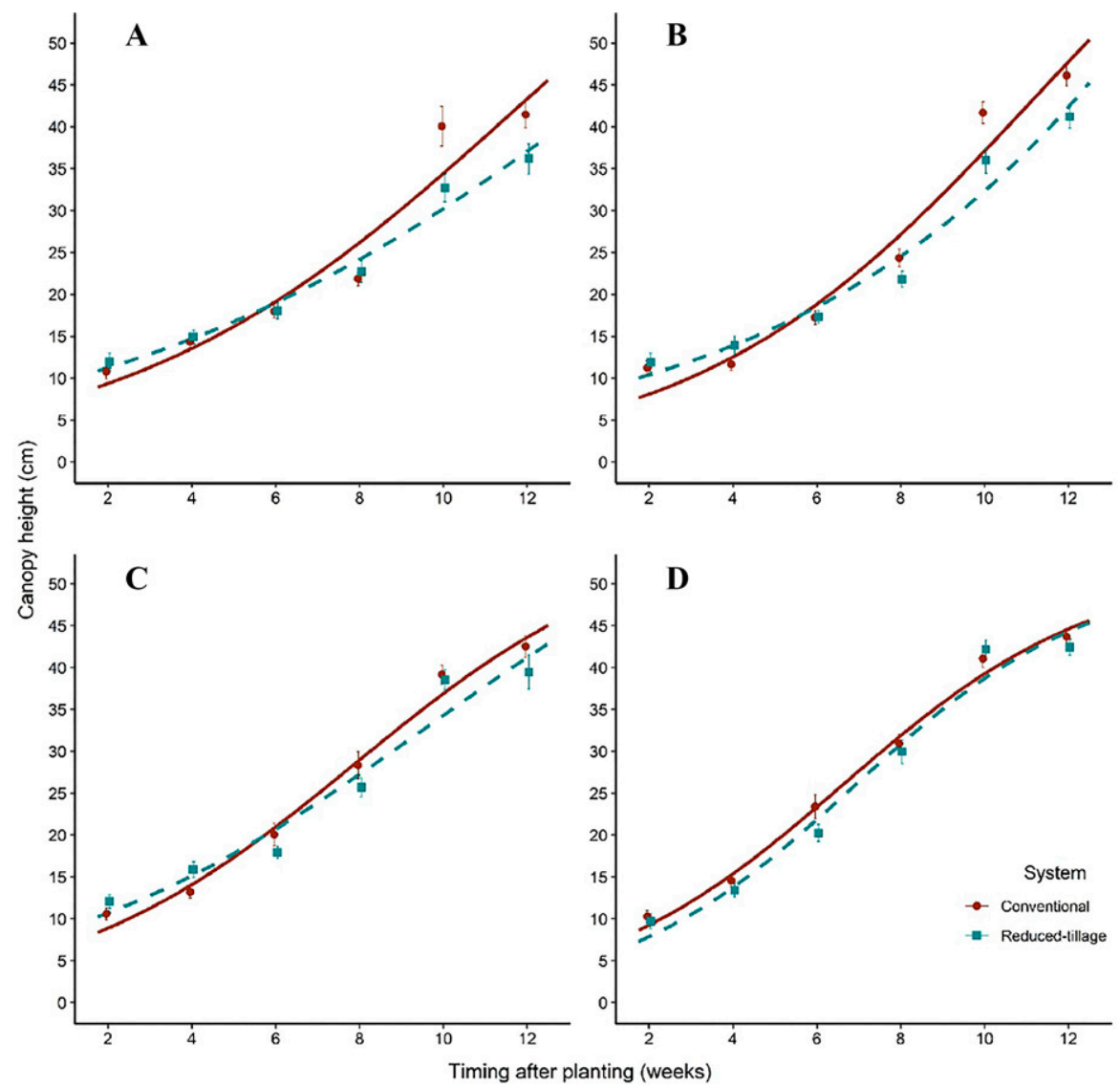

Fig. 1. Effect of 'Covington' (A), 'Bayou Belle' (B), 'NC04-0531' (C), and 'NC15-0650' (D) sweetpotato cultivars cultivated in conventional or a reducedtillage rye production system on crop canopy height from 2 to 12 weeks after planting. Data fit to the formula: $Y=a /[(1+c) \times \exp (-b \times T)]$, where $Y$ is the sweetpotato canopy height, $a$ is the upper asymptote, $T$ is weeks after planting, $c$ and $b$ are constants. Parameter estimates, root mean square error; and modeling efficiency coefficient provided in Table $3 ; 1 \mathrm{~cm}=0.3937 \mathrm{inch}$.
Sweetpotato Yield. The interaction of cultivar and production system was not significant; therefore, only main effects are presented. The conventional tillage system had $17 \%$ more marketable storage roots than the reduced-tillage rye system (Table 6); however, no differences in other root grade counts or yield by weight were observed between the two systems. 'Bayou Belle' had 53\% and 66\% greater marketable yield than 'Covington' and 'NC15-0650', respectively (Table 7). 'Covington' and 'NC15-0650' had $100 \%$ and $86 \%$ greater marketable yield than 'NC04-0531'. 'Bayou Belle' and 'NC15-0650' had similar No. I yield which was greater than 'Covington' and 'NC04-0531'. 'Bayou Belle' also had the greatest cull yield. Storage root counts by cultivar showed a similar trend to yield weights (Table 8).

Production system did not have a significant effect on storage root shape. 'NC15-0650' and 'NC04-531' had the greatest length to width ratios (Table 9). 'Covington' had a length/ width ratio of 1.69 , which is much smaller than the 2 to 1 length/width ratio typical of this cultivar (Yencho et al., 2008).

\section{Conclusion}

Sweetpotato grown in the conventional system performed better overall than those grown in the reduced-tillage rye system. Sweetpotato plants had greater canopy growth and produced more storage roots in the conventional system. The differences observed in canopy growth have significant implications for weed management. Large crop canopies are better able to compete for light than small canopies (Seavers 
Table 5. Effect of conventional or a reduced-tillage rye sweetpotato production system on soil bulk density at 2 and 10 weeks after planting (WAP).

\begin{tabular}{llc}
\hline & 2 WAP & 10 WAP \\
\cline { 2 - 3 } Production system & \multicolumn{2}{c}{ Soil bulk density $\left(\mathrm{g} \cdot \mathrm{cm}^{-3}\right)^{\mathrm{z}}$} \\
\hline Conventional & $1.35 \mathrm{a}^{\mathrm{y}}$ & $1.49 \mathrm{a}$ \\
Reduced-tillage rye $^{\mathrm{x}}$ & $1.42 \mathrm{~b}$ & $1.59 \mathrm{~b}$ \\
\hline
\end{tabular}

${ }^{\mathrm{z}} 1 \mathrm{~g} \cdot \mathrm{cm}^{-3}=0.5780 \mathrm{oz} / \mathrm{inch}^{3}$.

${ }^{y}$ Means within a column followed by the same letter are not different according to Tukey's honestly significant difference test of $P \leq 0.05$.

${ }^{x}$ Reduced-tillage rye production system consisted of sweetpotato transplanted through a standing rye cover crop onto beds. No in-season cultivation was conducted.

Table 6. Effect of conventional or a reduced-tillage rye production system on sweetpotato marketable storage root count.

\begin{tabular}{lc}
\hline Production system & Marketable storage root $(\text { no. } / \mathbf{h a})^{\mathrm{z}}$ \\
\hline Conventional tillage & $66,700 \mathrm{a}^{\mathrm{y}}$ \\
Reduced-tillage rye ${ }^{\mathrm{x}}$ & $56,800 \mathrm{~b}$ \\
\hline${ }^{\mathrm{z}}$ Marketable root count was calculated as total of all roots minus cull roots; l root/ha $=0.4047$ root/acre. \\
${ }^{{ }^{y}}$ Means within a column followed by the same letter are not different according to Tukey's honestly significant \\
difference test of $P \leq 0.05$.
\end{tabular}

Table 7. Effect of four sweetpotato cultivars on sweetpotato storage root yield by grade.

\begin{tabular}{lcrrll}
\hline & Marketable $^{\mathrm{z}}$ & US No. $\mathbf{~}^{\mathrm{z}}$ & Jumbo $^{\mathrm{z}}$ & Canner $^{\mathrm{z}}$ & Cull $^{\mathbf{z}}$ \\
\cline { 2 - 6 } Cultivar & \multicolumn{5}{c}{ Storage root yield $\left(\mathrm{kg} \cdot \mathrm{ha}^{-1}\right)^{\mathbf{y}}$} \\
\hline Covington & $22,300 \mathrm{~b}$ & $12,000 \mathrm{~b}$ & $7,740 \mathrm{~b}$ & $830 \mathrm{bc}$ & $780 \mathrm{~b}$ \\
Bayou Belle & $34,100 \mathrm{a}$ & $18,000 \mathrm{a}$ & $13,300 \mathrm{a}$ & $1,160 \mathrm{ab}$ & $1,400 \mathrm{a}$ \\
NC04-0531 & $11,100 \mathrm{c}$ & $8,500 \mathrm{~b}$ & $1,870 \mathrm{c}$ & $750 \mathrm{c}$ & $330 \mathrm{c}$ \\
NC15-0650 & $20,600 \mathrm{~b}$ & $17,100 \mathrm{a}$ & $1,490 \mathrm{c}$ & $1,610 \mathrm{a}$ & $370 \mathrm{bc}$ \\
\hline
\end{tabular}

${ }^{\mathrm{z}}$ Marketable root yield was calculated as total yield minus the cull yield. Jumbo roots are $>3.5$ inches in diameter, US No. 1 roots are $>1.75$ inch but $<3.5$ inches diameter and $>3$ inches but $<9$ inches in length, and canner roots are $>1$ inch but $<1.75$ inch diameter and $>2$ inch but $<7$ inches in length. Cull roots are misshapen or otherwise unmarketable; 1 inch $=2.54 \mathrm{~cm}$.

${ }^{\mathrm{y}} 1 \mathrm{~kg} \cdot \mathrm{ha}^{-1}=0.8922 \mathrm{lb} / \mathrm{acre}$.

${ }^{x}$ Means within a column followed by the same letter are not different according to Tukey's honestly significant difference test of $P \leq 0.05$.

Table 8. Effect of four sweetpotato cultivars on sweetpotato storage root count by grade.

\begin{tabular}{llllll}
\hline & Marketable $^{\mathbf{z}}$ & US No. I $^{\mathbf{z}}$ & Jumbo $^{\mathbf{z}}$ & Canner $^{\mathbf{z}}$ & Cull $^{\mathbf{z}}$ \\
\cline { 2 - 6 } Cultivar & \multicolumn{5}{c}{ Storage roots $(\text { no. } / \mathbf{h a})^{\mathrm{y}}$} \\
\hline Covington & $56,800 \mathrm{~b}^{\mathrm{x}}$ & $43,900 \mathrm{~b}$ & $11,200 \mathrm{~b}$ & $14,000 \mathrm{bc}$ & $7,320 \mathrm{ab}$ \\
Bayou Belle & $84,900 \mathrm{a}$ & $65,800 \mathrm{a}$ & $17,500 \mathrm{a}$ & $19,000 \mathrm{ab}$ & $9,590 \mathrm{a}$ \\
NC04-0531 & $36,700 \mathrm{c}$ & $33,200 \mathrm{~b}$ & $2,710 \mathrm{c}$ & $12,200 \mathrm{c}$ & $3,910 \mathrm{~b}$ \\
NC15-0650 & $68,600 \mathrm{ab}$ & $65,300 \mathrm{a}$ & $2,660 \mathrm{c}$ & $25,600 \mathrm{a}$ & $4,090 \mathrm{~b}$ \\
\hline
\end{tabular}

${ }^{\mathrm{z}}$ Marketable root vield was calculated as total vield minus the cull yield. Jumbo roots are $>3.5$ inches in diameter, US No. 1 roots are $>1.75$ inch but $<3.5$ inches diameter and $>3$ inches but $<9$ inches in length, canner roots are $>1$ inch but $<1.75$ inch diameter and $>2$ inch but $<7$ inches in length. Cull roots are misshapen or otherwise unmarketable; 1 inch $=2.54 \mathrm{~cm}$.

${ }^{\mathrm{y}} 1 \mathrm{root} / \mathrm{ha}=0.4047 \mathrm{root} / \mathrm{acre}$.

${ }^{\mathrm{x}}$ Means within a column followed by the same letter are not different according to Tukey's honestly significant difference test of $P \leq 0.05$. 
Table 9. Effect of four sweetpotato cultivars on sweetpotato storage root length to width ratio.

\begin{tabular}{lc}
\hline Cultivar & Length to width ratio \\
\hline Covington & $1.69 \mathrm{c}^{\mathrm{z}}$ \\
Bayou Belle & $1.86 \mathrm{~b}$ \\
NC04-0531 & $1.92 \mathrm{ab}$ \\
NC15-0650 & $2.05 \mathrm{a}$ \\
\hline
\end{tabular}

${ }^{\mathrm{z}}$ Means within a column followed by the same letter are not different according to Tukey's honestly significant difference test of $P \leq 0.05$.

and Wright, 2002). Large canopies can also serve to outcompete later emerging weeds. This suggests that conventional tillage systems result in a more competitive crop than reduced-tillage rye systems. Due to the reduced rate of canopy width expansion of upright cultivars, relative to prostrate cultivars, cultivation to control weeds can occur longer in the season in upright cultivars compared with the prostrate cultivars if grown in a conventional system.

Refinement of reduced-tillage rye sweetpotato production systems is needed before grower adoption. Current methods require additional inputs such as rye seed and off-season fertilizer that is not necessary in conventional production systems. Storage root yield and soil health benefits must be greater in the reduced-tillage rye production system before grower adoption. Future research should focus on methods to decrease input costs and increase yields in reduced-tillage rye production systems.

\section{Literature cited}

Beam, S.C., K.M. Jennings, S. Chaudhari, D.W. Monks, J.R. Schultheis, and M. Waldschmidt. 2018. Response of sweetpotato cultivars to linuron rate and application time. Weed Technol. 32(6):665-670, https://doi.org/10.1017/wet.2018.68.

Blanco-Canqui, H., L.R. Stone, A.J. Schlegel, J.G. Benjamin, M.F. Vigil, and P.W. Stahlman. 2010. Continuous cropping systems reduce near-surface maximum compaction in no-till soils. Agron. J. 102(4): 1217-1225, https://doi.org/10.2134/ agronj2010.0113.
Bloodworth, H. and M. Lane. 1994. Sweetpotato response to cover crops and conservation tillage. U.S. Dep. Agr., Nat. Res. Conserv. Serv. Tech. Note No. 9.

Daigh, A.L., M.J. Helmers, E. Kladivko, X. Zhou, R. Goeken, J. Cavdini, D. Barker, and J. Sawyer. 2014. Soil water during the drought of 2012 as affected by rye cover crops in fields in Iowa and Indiana. J. Soil Water Conserv. 69(6):564-573, https://doi.org/10.2489/jswc.69.6.564.

DeLaune, P.B., P. Mubvumba, K.L. Lewis, and J.W. Keeling. 2019. Rye cover crop impacts soil properties in a longterm cotton system. Soil Sci. Soc. Amer. J. 83(5):1451-1458, https://doi.org/ 10.2136/sssaj2019.03.0069.

Harrison, H.F. and D.M. Jackson. 2011. Response of two sweet potato cultivars to weed interference. Crop Prot. 30(10): 1291-1296, https://doi.org/10.1016/j. cropro.2011.05.002.

Hartwig, N.L. 1988. Crownvetch and min- or no-tillage crop production for soil erosion control. Weed Sci. Soc. Amer. 28:98 (abstr.).

Hou, X., R. Li, Z. Jia, Q. Han, W. Wang, and B. Yang. 2012. Effects of rotational tillage practices on soil properties, winter wheat yields and water-use efficiency in semi-arid areas of north-west China. Field Crops Res. 129:7-13, https://doi.org/ 10.1016/j.fcr.2011.12.021.

Kessavalou, A. and D.T. Walters. 1999. Winter rye cover crop following soybean under conservation tillage: Residual soil nitrate. Agron. J. 91(4):643-649, https://doi.org/10.2134/agronj1999.91 4643x.

Langdale, G.W. and R.A. Leonard. 1983. Nutrient cycling in agricultural ecosystems: Nutrient and sediment losses associated with conventional and reduced tillage agricultural practices. Univ. Georgia College Agric. Spec. Publ. No. 23.

Moore, E.B., M.H. Wiedenhoeft, T.C. Kaspar, and C.A. Cambardella. 2014. Rye cover crop effects on soil quality in no-till corn silage-soybean cropping systems. Soil Sci. Soc. Amer. J. 78(3):968-976, https://doi. org/10.2136/sssaj2013.09.0401.

Nwosisi, S., D. Nandwani, and D. Hui. 2019. Mulch treatment effect on weed biomass and yields of organic sweetpotato cultivars. Agronomy 9(4):190 (abstr.), https://doi.org/10.3390/agronomy9040 190.

Seavers, G.P. and K.G. Wright. 2002. Crop canopy development and structure influence weed suppression. Weed Res. 39(4): 319-328, https://doi.org/10.1046/ j.1365-3180.1999.00148.x.

Smith, A.N., S.C. Reberg-Horton, G.T. Place, A.D. Meijer, C. Arellano, and J.P. Mueller. 2011. Rolled rye mulch for weed suppression in organic no-tillage soybeans. Weed Sci. 59(2):224-231, https://doi. org/10.1614/WS-D-10-00112.1.

Smith, S.C., K.M. Jennings, D.W. Monks, S. Chaudhari, J.R. Schultheis, and S.C. Reberg-Horton. 2020. Critical timing of palmer amaranth (Amaranthus palmeri) removal in sweetpotato. Weed Technol. 34(4):1-19, https://doi.org/10.1017/ wet.2020.1.

Treadwell, D.D., N.G. Creamer, J.R. Schultheis, and G.D. Hoyt. 2007. Cover crop management affects weeds and yield in organically managed sweetpotato systems. Weed Technol. 21(4):1039-1048, https://doi.org/10.1614/WT-07-005.1.

U.S. Department of Agriculture, National Agricultural Statistics Service. 2019. NASS_quick stats. 2 Nov. 2020. $<$ https://data.nal.usda.gov/dataset/nassquick-stats $>$.

U.S. Department of Agriculture, Agriculture Marketing Service. 2019. Sweetpotato grades and standards. 2 Nov. 2020. <https://www.ams.usda.gov/grades-stand ards/sweetpotatoes-grades-and-standards $>$.

U.S. Department of Agriculture, Natural Resource Conservation Service. 2008. Soil bulk density/moisture/aeration. 2 Nov. 2020. <https://www.nrcs.usda.gov/Inter net/FSE_DOCUMENTS/nrcs142p2_053 260.pdf $>$.

Yencho, G.C., K.V. Pecota, J.R. Schultheis, Z. VanEsbroeck, G.J. Holmes, B.E. Little, A.C. Thornton, and V. Truong. 2008. 'Covington' sweetpotato. HortScience 43(6): 1911-1914, https://doi.org/10.21273/ HORTSCI.43.6.1911.

Yenish, J.P., A.D. Worsham, and A.C. York. 1996. Cover crops for herbicide replacement in no-tillage corn (Zea mays). Weed Technol. 10(4):815-821, https:// doi.org/10.1017/S0890037X00040859. 